\title{
Analisis Empiris Faktor Determinan Struktur Modal Perusahaan Infrastruktur Indonesia
}

\section{Empirical Analysis of Capital Structure in Indonesia's Infrastructure Companies}

\author{
Alexandra Christivera ${ }^{1}$, Desya Gunawan ${ }^{1}$, Donna Jovita Fendi ${ }^{{ }^{*}}$ \\ 1) Sekolah Bisnis dan Ekonomi, Universitas Prasetiya Mulya, Kampus BSD City Tangerang 15339
}

\begin{abstract}
The Infrastructure Industry has become the focus of the state expenditure budget during the Joko Widodo-Jusuf Kalla presidency. This is due to the importance of infrastructure in assisting the sustainability of a country's development, but the fact is that government funds as a source of infrastructure funds are delayed when the company has acquired a new project resulting in the use of debt in infrastructure companies as a capital structure to run the new project. The study identifies examination on the impact of capital structure determinants on firm financial performance of Indonesia's Infrastructure Companies listed over the period of 2014-2018. Determination of the number of samples in this study using non-probability sampling, specifically purposive sampling method. The study uses one capital structure measures (Leverage) as dependent variable and four performance measures (including company's size, the tangibility of asset, liquidity, and asset turnover) as independent variables and proceed using multiple regression model. The result indicates that liquidity has a significantly negative relationship to leverage, meanwhile company's size, the tangibility of asset, and asset turnover are not significantly related to the level of debt in infrastructure companies in Indonesia, however, it goes along with the way of thinking in the Pecking Order Theory.
\end{abstract}

Keywords: capital structure, company performance, infrastructure companies, pecking order theory.

\begin{abstract}
ABSTRAK
Industri Infrastruktur telah menjadi fokus Anggaran Pendapatan dan Belanja Negara (APBN) pada masa pemerintahan Joko Widodo-Jusuf Kalla. Hal ini dikarenakan pentingnya infrastruktur dalam membantu pembangunan keberlanjutan suatu negara, namun faktanya dana pemerintah sebagai sumber dana perusahaan infrastruktur tertunda disaat perusahaan telah mendapatkan proyek baru mengakibatkan perusahaan infrastruktur memakai utang sebagai struktur modal untuk menjalankan proyek baru tersebut. Studi ini mengidentifikasi dampak struktur modal pada kinerja perusahaan terbuka Infrastruktur Indonesia yang terdaftar pada tahun 2014-2018. Penentuan sampel menggunakan nonprobability sampling, khususnya metode purposive sampling. Penelitian ini memakai satu pengukuran struktur modal (utang) sebagai variabel dependen dan empat pengukuran kinerja perusahaan (termasuk company's size, the tangibility of asset, liquidity, and asset turnover) sebagai variabel independen dan diolah menggunakan multiple regression. Hasil penelitian menunjukkan bahwa liquidity memiliki hubungan yang secara signifikan negatif terhadap leverage, sedangkan company's size, the tangibility of asset, dan asset turnover tidak berpengaruh secara signifikan terhadap tingkat utang perusahaan Infrastruktur di Indonesia, namun mengikuti penalaran pada Teori Pecking Order.
\end{abstract}

Kata Kunci: struktur modal, performa perusahaan, perusahaan infrastruktur, teori pecking order.

*Corresponding author

Alamat e-mail: donna.fendi@student.pmsbe.ac.id 


\section{PENDAHULUAN}

Percepatan bagi pembangunan infrastruktur dapat menjaga keberlanjutan pertumbuhan ekonomi Indonesia untuk meraih cita-cita Indonesia negara maju 2045. Oleh karena itu, pembangunan secara masif dilakukan mulai dari jalan tol sampai dengan infrastruktur transportasi massal seperti mass rapid transit (MRT). Menurut APWA (American Public Works Association), infrastruktur merupakan fasilitas, struktur dasar maupun instalasi yang memiliki komponen seperti fasilitas gas alam, sistem penyediaan dan pengelolaan air, fasilitas pengendalian banjir, lintas air dan navigasi, fasilitas transportasi (seperti jalan tol, rel kereta, bandar udara) sistem transit publik, sistem kelistrikan, gedung publik (seperti sekolah dan rumah sakit), fasilitas perumahan, komunikasi, dan taman kota.

Tidak dapat dihindari bahwa beberapa Badan Usaha Milik Negara (BUMN) ditunjuk sebagai pengembang proyek infrastruktur utama. Biasanya, perusahaan ini memiliki aset yang lebih besar ketimbang swasta dan mampu mengumpulkan dana tambahan dari bank BUMN lebih mudah. Kebutuhan dana untuk pembangunan ini kemudian ditandai dengan kenaikan alokasi APBN sejumlah $\mathrm{Rp}$ 410,7 T di tahun 2018 dibandingkan dengan $\mathrm{Rp}$ 256,1 $\mathrm{T}$ di tahun 2015 (Kemenkeu: APBN, 2019). Namun, dana APBN sendiri tidak cukup untuk mendanai semua proyek infrastruktur secara keseluruhan. Berdasarkan perkiraan kebutuhan pendanaan Rencana Pembangunan Jangka Menengah Nasional (RPJMN) 2015-2019, diketahui bahwa persentase APBN, APBD, BUMN, dan swasta yaitu sebesar 40,14 persen, 9,88 persen, 19,32 persen, dan 30,66 persen secara berurutan. Terlihat bahwa separuh dari dana yang dibutuhkan untuk proyek dengan total sebesar Rp 5.519,4 $\mathrm{T}$ bersumber dari BUMN dan swasta. Hal ini kemudian mendorong peningkatan pembiayaan melalui utang oleh sejumlah emiten infrastruktur yang menjadi perpanjangan tangan Pemerintah dalam proyek yang digarap.

Tren perusahaan infrastruktur dalam pembiayaan melalui utang ini sejalan dengan Pecking Order Theory oleh Myers dan Majluf (1984). Berdasarkan teori tersebut, perusahaan dalam metode pembiayaannya cenderung lebih memilih untuk menggunakan internal financing dari profit yang dihasilkan, lalu utang (leverage) dan right issues sebagai pilihan terakhir. Hal ini dikarenakan pengemuka teori ini beranggapan struktur modal perusahaan melambangkan kualitas kinerja perusahaan. Apabila perusahaan tersebut dapat membiayai usahanya dengan pendapatannya, maka perusahaan tersebut dapat dibilang kuat. Lalu, dengan perusahaan berhutang dapat memberikan kesan bahwa perusahaan percaya diri dalam memenuhi kewajibannya. Sedangkan, right issue justru dapat memberikan kesan negatif, yaitu perusahaan beranggapan saham mereka overvalued dan perusahaan berusaha untuk menghasilkan uang sebelum harga saham mereka turun. Sehingga, hierarki pendanaan menurut Pecking Order Theory dijabarkan yaitu (1) pendanaan internal yang berasal dari laba ditahan, (2) pendanaan utang dengan menerbitkan obligasi dan menggunakan (3) penerbitan saham sebagai pilihan pendanaan yang terakhir.

Pemilihan utang sebagai sumber utama pendanaan struktur modal perusahaan infrastruktur dapat terbagi menjadi dua bagian secara umum, yaitu berasal dari faktor internal dan eksternal. Namun, pada karya tulis ini faktor eksternal tidak menjadi perhatian karena kondisi tersebut (makro ekonomi Indonesia) secara umum memengaruhi semua perusahaan dalam bidang manapun. Maka, penulis mengkaji lebih jauh mengenai pengaruh faktor internal perusahaan (company's size, the tangibility of asset, liquidity dan asset turnover) infrastruktur di Indonesia yang bisa menunjukkan kinerja perusahaan. Beberapa determinan yang digunakan oleh penulis dipilih berdasarkan teori struktur modal Pecking Order Theory. Berdasarkan teori ini, company's size perlu menjadi pertimbangan dalam pemilihan struktur modal. Menurut Bhagat, Bolton dan $\mathrm{Lu}$ (2015), besarnya suatu perusahaan mempengaruhi level of debt dari sebuah perusahaan. Hal ini dikarenakan semakin besar ukuran perusahaan dapat menunjukkan kemampuan dan risiko yang dapat ditanggung oleh perusahaan tersebut. The tangibility of asset sebuah perusahaan juga bisa menjadi salah satu determinan dari leverage karena sudah menjadi sebuah fakta dengan adanya jumlah tangible asset yang cukup besar dapat dijadikan sebagai jaminan perusahaan apabila perusahaan terkait tidak mampu dalam memenuhi kewajibannya. Liquidity menjadi salah 
satu faktor pertimbangan karena rasio ini dapat menunjukkan besarnya kas yang dimiliki perusahaan untuk pembiayaan investasinya atau utangnya. Kemudian determinan terakhir adalah asset turnover yang dapat menunjukkan seberapa efisien suatu perusahaan dalam menggunakan aset yang telah diinvestasikan, dalam hal ini adalah leverage-nya.

Oleh karena itu, peneliti memprioritaskan empat determinan penelitian ini, yaitu company's size, the tangibility of asset, liquidity, dan asset turnover terhadap keputusan pembiayaan utang dalam pembentukan struktur permodalan perusahaan infrastruktur yang terdaftar pada Bursa Efek Indonesia mulai tahun 2014 hingga 2018. Manfaat dari penelitian terkait adalah untuk mengetahui signifikansi determinan yang dapat menjadi pertimbangkan bagi perusahaan dalam pengambilan keputusan pembiayaan utang yang dapat berdampak pada performa finansial perusahaan.

\section{Tinjauan Pustaka}

Teori mengenai struktur modal telah berkembang dari waktu ke waktu mulai dari munculnya The Net Operating Income Approach (pendekatan penghasilan operasional bersih), The Net Income Approach (pendekatan penghasilan bersih), dan Traditional Approach (pendekatan Tradisional). Setelah itu, disusul oleh munculnya teori struktur modal modern oleh Franco Modigliani dan Merton Miller pada tahun 1958. Meskipun munculnya teori ini sangat bermanfaat bagi perkembangan teori struktur modal, namun teori ini kurang relevan dengan realita perusahaan karena menggunakan asumsi pasar modal sempurna yang bertentangan dengan realita keadaan pasar modal yang tidak sempurna. Ketidaksempurnaan pasar modal dilihat dari adanya pajak, informasi yang asimetris, biaya transaksi, biaya kebangrutan, dan terjadinya perubahan biaya utang saat proporsi jumlah dalam utang berubah (Sudana \& Radjamin, 2014).

Oleh sebab itu, perkembangan teori struktur modal selanjutnya yakni Trade off Theory dan Pecking Order Theory disesuaikan agar lebih relevan dengan kondisi riil pada pasar modal. Pecking Order Theory dinilai memiliki lebih banyak relevansi terhadap pengambilan keputusan pembiayaan perusahaan Infrastruktur ketimbang teori lainnya (Myers \& Majluf, 1984). Namun, terdapat variasi hasil penelitian-penelitian terdahulu mengenai signifikansi faktor determinan pembuatan keputusan pembiayaan melalui utang sebagai sumber utama pendanaan perusahaan infrastruktur. Hal ini dikarenakan penelitian dilakukan di berbagai negara seperti Turki, India, Sri Lanka, Malaysia, dan sebagainya dimana tiap perusahaan pada masing-masing negara memiliki perbedaan kondisi internal maupun eksternal. Untuk itu, penulis akan meneliti signifikansi empat faktor internal perusahaan yaitu company's size, the tangibility of asset, liquidity dan asset turnover terhadap pembentukan struktur modal perusahaan Infrastruktur di Indonesia.

\section{Company's Size}

Selain faktor eksternal dalam menentukan struktur modal perusahaan, faktor internal juga berkaitan dengan keputusan pemilihan struktur modal seperti company's size, the tangibility of assets, liquidity dan asset turnover. Terdapat variasi hasil dari beberapa penelitian terdahulu mengenai keterkaitan faktor determinan internal pada struktur modal perusahaan. Berdasarkan hasil studi (Handoo \& Sharma, 2014; Alipour, 2015; Kurshev \& Strebulaev, 2015; Seikh, 2016) tentang hubungan company's size dan company's leverage sebagian besar telah membuktikan bahwa memiliki hubungan yang positif. Hasil ini konsisten dengan trade off theory yang menyatakan bahwa semakin besar ukuran sebuah perusahaan akan memiliki kecenderungan untuk menggunakan proporsi utang yang lebih besar. Namun, terdapat peneliti lain yang membuktikan perbedaan hasil regresi dimana Thippayana (2014) menyatakan hubungan negatif antara company's size dengan leverage yang ditentukan melalui natural logaritma dari total aset suatu perusahaan karena sejalan dengan prediksi Pecking Order Theory bahwa semakin besar ukuran sebuah perusahaan, maka kemungkinan perusahaan tersebut berhutang akan semakin kecil, karena berdasarkan penelitian tersebut perusahaan dipercaya dapat menghasilkan pendapatan yang cukup besar untuk dilakukannya internal financing. 


\section{The Tangibility of Assets}

Beberapa studi menyatakan bahwa pada negara berkembang, the tangibility of assets memiliki hubungan negatif dengan rasio utang karena tidak merepresentasikan jaminan bagi creditors apabila perusahaan borrower mengalami default (Serghiescu \& Văidean, 2014; Nivorozhkin, 2005). Namun, penelitian terbaru oleh Buvanendra, Sridharan, dan Thiyagarajan (2017) menyatakan bahwa pengaruh tangibility signifikan bagi perusahaan di India. Hal ini mengimplikasikan bahwa struktur aset suatu perusahaan memiliki peran yang dominan bagi kapasitas utangnya, karena pada negara India terdapat asimetris informasi yang rendah. Handoo dan Sharma (2014) juga membuktikan bahwa asset tangibility memiliki pengaruh yang signifikan terhadap struktur permodalan dalam perusahaan yang dikaji yaitu perusahaan di India.

\section{Liquidity}

Berdasarkan hasil studi dari Sharma dan Paul (2015), liquidity sebuah perusahaan memiliki hubungan yang positif terhadap leverage perusahaan tersebut. Hal ini terjadi karena perusahaan tersebut sedang menjalankan prinsip kehati-hatian dimana perusahaan harus memegang aset likuid untuk menanggung leverage perusahaan yang tinggi. Handoo dan Sharma (2014) membuat 3 model regresi terhadap perusahaan di India dan menemukan bahwa liquidity tidak memiliki dampak signifikan terhadap keputusan perusahaan untuk menggunakan short-term debt, longterm debt, dan total debt. Rashid dan Mahmood (2017) juga menyatakan bahwa liquidity memiliki hubungan yang negatif terhadap penggunaan leverage. Hal ini disebabkan karena perusahaan yang likuid memiliki kecenderungan untuk menambah modal dengan right issue. Oleh karena itu, hal ini dapat mengurangi leverage ratio perusahaan.

\section{Asset Turnover}

Menurut studi yang dilakukan oleh Muritala (2018), asset turnover, size, firm's age, dan firm's asset tangibility memiliki hubungan yang positif terhadap struktur modal yang dimiliki oleh perusahaan. Karena semakin besar modal yang dimiliki perusahaan tentu akan menghasilkan profit yang besar pula. Namun, hasil dari studi yang dilakukan oleh Serghiescu dan Văidean (2014) menyatakan bahwa asset turnover merupakan variabel independent berhubungan negatif dengan level of debt perusahaan. Hal ini searah dengan Pecking Order Theory yang menyatakan bahwa perusahaan yang menghasilkan profit dan memiliki tingkat likuiditas yang tinggi akan memiliki level of debt yang rendah. Berdasarkan serangkaian penemuan dari para ahli, maka dapat dinyatakan bahwa beberapa penemuan memiliki hasil yang berbeda. Walaupun jurnal-jurnal terkait meneliti struktur modal perusahaan di sektor infrastruktur, penelitian tersebut kebanyakan dilakukan di luar Indonesia. Sehingga, dalam perusahaan infrastruktur di Indonesia akan cenderung melakukan pemakaian strategi Pecking Order Theory dalam pemilihan struktur modal yang memilih utang sebagai sumber pendanaan perusahaan yang kemudian diikuti dengan ekuitas. Teori ini memprediksi hubungan negatif antara leverage dengan liquidity dan company's size sedangkan leverage berhubungan positif terhadap tangibility of assets dan asset turnover (Yurtoğlu, 2018). 


\section{METODE PENELITIAN Kerangka Pemikiran}

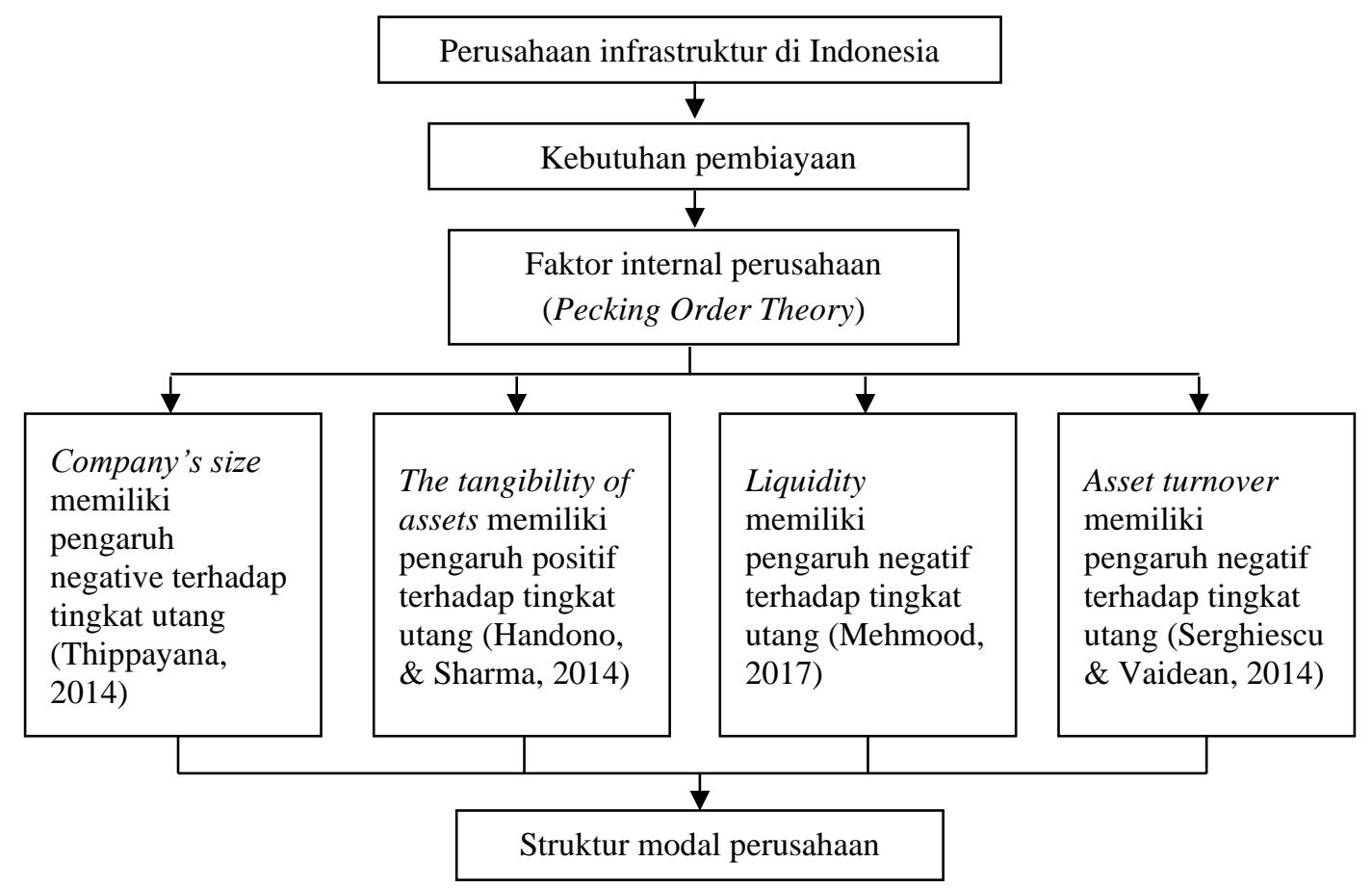

Gambar 1. Kerangka Pemikiran Struktur Modal Perusahaan Infrastruktur dalam Pecking Order Theory

Perusahaan Infrastruktur sebagai suatu organisasi membutuhkan dana sebagai penunjang operasional. Sumber utama pendanaan perusahaan infrastruktur berasal dari utang, maka dalam memperoleh modal tersebut perusahaan harus mempertimbangkan serangkaian indikator internal perusahaan agar mendapatkan struktur modal yang ideal bagi perusahaan. Seiring dengan perkembangan teori mengenai struktur modal, Pecking Order Theory memiliki lebih banyak relevansi terhadap pengambilan keputusan pembiayaan perusahaan Infrastruktur ketimbang teori lainnya (Myers \& Majluf, 1984). Namun, terdapat variasi hasil penelitian-penelitian terdahulu mengenai signifikansi faktor determinan pembuatan keputusan pembiayaan melalui utang. Hal ini dikarenakan penelitian dilakukan di berbagai negara seperti Turki, India, Sri Lanka, Malaysia, dan sebagainya dimana tiap perusahaan pada masing-masing negara memiliki perbedaan kondisi internal maupun eksternal. Untuk itu, penulis akan meneliti signifikansi empat faktor internal perusahaan yaitu company's size, the tangibility of assets, liquidity dan asset turnover terhadap pembentukan struktur modal perusahaan Infrastruktur di Indonesia.

Mengacu pada Pecking Order Theory, faktor yang berhubungan negatif dengan utang yaitu: (1) company's size; (2) liquidity, dan; (3) asset turnover. Disisi lain, faktor yang berhubungan positif dengan utang adalah (4) the tangibility of asset. Hasil penelitian Serghiescu dan Văidean (2014) mengungkapkan bahwa terdapat hubungan negatif antara company's size dengan utang dimana semakin besar ukuran sebuah perusahaan, maka kemungkinan perusahaan tersebut berhutang akan semakin kecil karena perusahaan dipercaya dapat menghasilkan pendapatan yang cukup besar untuk dilakukannya internal financing (Thippayana, 2014). Kemudian, hubungan negatif antara liquidity dan utang dinyatakan oleh Rashid dan Mahmood (2017) dimana perusahaan yang likuid memiliki kecenderungan untuk menambah modal dengan right issue sehingga mengakibatkan penurunan leverage ratio perusahaan. Variabel lainnya yang berhubungan negatif dengan utang adalah asset turnover, dimana asset turnover yang rendah menandakan perusahaan menghasilkan pendapatan yang rendah relatif pada asetnya. Oleh karena itu, leverage akan menjadi tinggi karena perusahaan tidak memiliki cukup dana dari internal untuk membiayai aset yang sedang berlangsung (Serghiescu \& Văidean, 2014). 
Di sisi lain, faktor yang berhubungan positif dengan tingkat utang menurut Pecking Order Theory adalah the tangibility of asset perusahaan. Buvanendra dan Thiyagarajan (2017) dan Handoo dan Sharma (2014) mengungkapkan bahwa struktur aset suatu perusahaan memiliki peran yang dominan bagi kapasitas utangnya terutama pada negara yang memiliki asimetris informasi yang rendah.

\section{Metode Pengumpulan Data}

Data sampel diolah menggunakan cross-sectional data dan time series yang dilakukan pada 28 perusahaan yang terbagi menjadi 7 sektor yaitu perusahaan energi, konstruksi, non-konstruksi bangunan, telekomunikasi, pembangunan jalan tol, transportasi, dan properti real estat yang terdaftar pada Bursa Efek Indonesia (BEI) dan berasal dari data yang dikumpulkan Indonesia Stock Exchange (IDX) dan data Bloomberg. Data yang diolah meliputi tahun 2014 sampai tahun 2018 dimana tahun tersebut merupakan tahun masa pemerintahan Jokowi yang memfokuskan pengalokasian APBN pada pengembangan sektor infrastruktur. Dengan mempertimbangkan 1 dependent variables leverage (DAR) dan empat independent variables yaitu company's size (SIZE), the tangibility of asset (TAN), liquidity (LIQ), dan asset turnover (TURN).

\section{Operasionalisasi Variabel}

Tabel 1. Operasionalisasi Tabel

\begin{tabular}{|c|c|c|}
\hline Variabel & Indikator & Deskripsi \\
\hline $\begin{array}{l}\text { Y: Leverage } \\
\text { (DAR) }\end{array}$ & $\begin{array}{l}\text { Debt to Total } \\
\text { Asset }\end{array}$ & $\begin{array}{l}\text { Debt to Total Asset merupakan indikator yang mampu } \\
\text { merefleksikan tingkat utang perusahaan. Oleh karena itu, } \\
\text { kemampuan perusahaan untuk membayar kewajiban jangka } \\
\text { panjangnya dapat diperhitungkan melalui pembiayaan aset yang } \\
\text { dibiayai oleh kreditur. }\end{array}$ \\
\hline $\begin{array}{l}\mathrm{X} 1: \text { Company's } \\
\text { size (SIZE) }\end{array}$ & $\log ($ Total Asset $)$ & $\begin{array}{l}\text { Perusahaan yang memiliki ukuran besar ( Log (Total Asset) } \\
\text { tinggi) cenderung memiliki arus kas yang lebih stabil sehinga } \\
\text { risiko default akan semakin kecil. Besarnya ukuran perusahaan } \\
\text { juga dapat mempermudah perusahaan untuk memperoleh dan } \\
\text { menjaga tingkat utang yang lebih tinggi. }\end{array}$ \\
\hline $\begin{array}{l}\mathrm{X} 2: \text { The } \\
\text { tangibility of } \\
\text { assets (TAN) }\end{array}$ & $\begin{array}{l}\text { Net Fixed Asset to } \\
\text { Total Asset }\end{array}$ & $\begin{array}{l}\text { The tangibility of assets (TAN) dapat menunjukkan seberapa } \\
\text { banyak aset yang dimiliki perusahaan yang dapat digunakan } \\
\text { sebagai "kolateral" untuk mengambil utang termasuk tanah, } \\
\text { bangunan, mesin, dan peralatan. }\end{array}$ \\
\hline $\begin{array}{l}\text { X3: Liquidity } \\
\text { (LIQ) }\end{array}$ & Current Ratio & $\begin{array}{l}\text { Liquidity (LIQ) dapat memperlihatkan kemampuan perusahaan } \\
\text { untuk dapat mengubah aset menjadi kas (marketability). Selain } \\
\text { itu, likuiditas juga mengukur kemampuan perusahaan untuk } \\
\text { dapat memenuhi kewajiban jangka pendeknya. }\end{array}$ \\
\hline $\begin{array}{l}\text { X4:Asset turnover } \\
\text { (TURN) }\end{array}$ & $\begin{array}{l}\text { Asset Turnover } \\
\text { Ratio }\end{array}$ & $\begin{array}{l}\text { Asset turnover (TURN) merupakan rasio yang menggambarkan } \\
\text { efisiensi pengelolaan aset suatu perusahaan untuk menghasilkan } \\
\text { keuntungan. }\end{array}$ \\
\hline
\end{tabular}

Penelitian yang dilakukan menganalisis pengaruh variabel independen yaitu company's size, the tangibility of asset, liquidity dan asset turnover terhadap leverage sebagai variabel dependen pada perusahaan infrastruktur di Indonesia. Berikut merupakan hipotesis dari penelitian ini.

$\mathrm{H}_{0}$ : Company's size, the tangibility of asset, liquidity, dan asset turnover tidak berpengaruh secara simultan terhadap pembuatan keputusan struktur pembiayaan perusahaan melalui utang.

$\mathrm{H}_{1}$ : Company's size, the tangibility of asset, liquidity, dan asset turnover berpengaruh secara

Jurnal Manajemen dan Organisasi (JMO),

Vol. 10 No. 3,
Desember 2019,

Hal. $147-158$ simultan terhadap pembuatan keputusan struktur pembiayaan perusahaan melalui utang.

\section{Metode Pengolahan dan Analisis Data}

Metode penelitian yang digunakan adalah analisis multiple regression yang diolah menggunakan aplikasi Eviews dengan sampel penelitian akan dilakukan terhadap 28 perusahaan 
infrastruktur yang tercatat di BEI baik perusahaan pemerintah maupun swasta. Berdasarkan regresi linear berganda maka didapatkan model sebagai berikut:

$$
\mathrm{DAR}_{\mathrm{it}}=\beta_{0}+\beta_{1} \mathrm{SIZE}_{\mathrm{it}}+\beta_{2} \mathrm{TAN}_{\mathrm{it}}+\beta_{3} \mathrm{LIQ}_{\mathrm{it}}+\beta_{4} \mathrm{TURN}_{\mathrm{it}}+\varepsilon_{\mathrm{it}}
$$

Dalam mengolah data regresi linear berganda terdapat asumsi klasik yang harus dipenuhi, dimana dua variabel yang diuji merupakan data yang berkelanjutan (continuous) dapat berupa variabel interval maupun rasio. Selanjutnya, data yang diolah perlu memiliki hubungan linear yang dipastikan dengan melakukan RESET Test pada Eviews statistics. Kemudian, data yang diolah tidak boleh memiliki data outlier (data poin yang bernilai sangat berbeda dari data yang diprediksi menggunakan garis persamaan regresi), adanya outlier mengindikasikan residual yang sangat besar sehingga meningkatkan standard error data yang diolah. Data observasi yang diolah juga harus memiliki independensi atau keterikatan variabel (autokorelasi) yang dapat diuji menggunakan Durbin-Watson Statistics. Selain itu, data yang diolah harus menunjukan homoscedasticity dimana variance pada garis BLUE (Best Linear Unbiased Estimator) akan bergerak secara serupa jika dipindahkan pada garis regresi. Asumsi homoskedastisitas ini dipastikan dengan melakukan Harvey-Godfrey Test. Kemudian, residual atau error pada garis regresi perlu terdistribusi secara normal (approximately normally distributed), normalitas residual diasumsikan dengan penggunaan teori Central Limit Theorem. Untuk memenuhi seluruh asumsi klasik multiple regression, maka dilakukan transformasi model (generalized difference equation) seperti berikut:

LOGDAR $_{t}-\rho$ LOGDAR $_{t-1}=\beta_{0}+\rho \beta_{0}+\beta_{1}$ LOGSIZE $_{t}-\rho \beta_{1}$ LOGSIZE $_{t-1}+\beta_{2}$ LOGTAN $_{t}-\rho \beta_{2}$ LOGTAN $_{t-1}+$ $\beta_{3}$ LOGLIQ $_{\mathrm{t}}-\rho \beta_{3}$ LOGLIQ $_{\mathrm{t}-1}+\beta_{4}$ LOGTURN $_{\mathrm{t}}-\rho \beta_{4}$ LOGTURN $_{\mathrm{t}-1}+\varepsilon_{\mathrm{t}}-\rho \varepsilon_{\mathrm{t}-1}$

di mana $\rho \approx 1-\frac{d}{2}, \mathrm{~d}=$ hasil statistik Durbin Watson

\section{HASIL DAN PEMBAHASAN}

Tabel 2. Data Statistik Deskriptif Perusahaan Infrastruktur di Indonesia Tahun 2014 - 2018

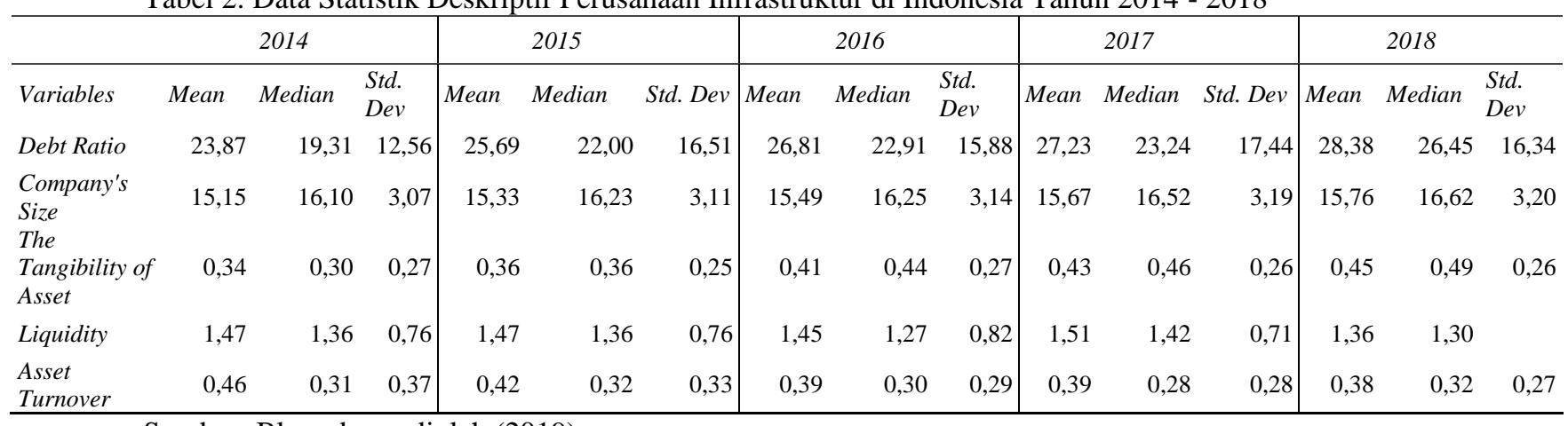

Sumber: Bloomberg, diolah (2019)

\section{Statistik Deskriptif}

Selama masa pemerintahan Jokowi-JK, secara rata - rata perusahaan infrastruktur memiliki utang yang diindikasikan menggunakan Debt to Total Asset (DAR) sebesar 26,39 persen dengan simpangan baku di angka 15,75. Berdasarkan hasil statistik, ditemukan bahwa DAR perusahaan infrastruktur pada tahun 2014 sampai 2018 memiliki nilai minimum sebesar 1,05 persen dan nilai maksimum sebesar 67,31 persen. Berdasarkan analisis statistik, didapatkan nilai rata - rata untuk perhitungan company's size sebesar 15,44 dengan nilai maksimum yaitu 19,14 dan nilai minimum yaitu 4,9. Dari data tersebut didapatkan simpangan baku sebesar 3,13 dengan skewness sebesar 2,1 . The tangibility of assets dapat menunjukkan seberapa banyak aset yang dimiliki perusahaan yang dapat digunakan sebagai kolateral untuk mengambil utang. Dari tabel di atas didapatkan rata - rata sebesar 0,401 dengan nilai tertinggi yaitu 0,866 dan nilai terendah yaitu 0 . Kemudian didapatkan juga hasil simpangan baku sebesar 0,26 dengan skewness sebesar -0,078.

Perhitungan liquidity dilihat dari besarnya current ratio perusahaan karena dapat memperlihatkan kemampuan perusahaan untuk dapat mengubah aset menjadi kas (marketability). Dalam lima tahun terakhir, rata-rata determinan ini adalah sebesar 1,46 dengan nilai tertinggi 
3,887 dan nilai terendah 0,115 dengan simpangan baku sebesar 0,765. Asset turnover merupakan rasio yang digunakan untuk mengukur efisiensi pengelolaan aset perusahaan dalam menghasilkan pendapatan. Berdasarkan tabel olahan data di atas, didapatkan rata-rata pada industri infrastruktur adalah 0,415 dengan nilai tertinggi sebesar 1,299 dan nilai terendah sebesar 0,012. Selain ratarata juga didapatkan simpangan baku sebesar 0,307 dengan skewness sebesar 1,126.

\section{Regresi Data Panel}

Pengujian asumsi klasik dari model regresi awal perlu dilakukan untuk memastikan bahwa model tersebut telah memenuhi kriteria akan valid atau tidaknya sebagai alat penduga. Model regresi tersebut akan mengalami penyesuaian model apabila model tersebut tidak memenuhi asumsi-asumsi tersebut, di antara nya adalah uji normalitas, uji multikolinearitas, uji heteroskedastisitas, uji linearitas, dan uji autokorelasi. Uji asumsi klasik pertama yang penulis lakukan adalah pengujian linearitas pada model yang menunjukkan hubungan linear antara variabel terikat dan variabel bebas. Uji ini dilakukan dengan menggunakan RESET Test dengan melihat apakah F-statistik yang dihasilkan oleh model lebih besar dari 0,05 dan dari tes tersebut dapat disimpulkan bahwa model baru tersebut memenuhi asumsi linearitas $(0,5804>0,05)$.

Selanjutnya dilakukan uji normalitas terhadap model regresi dimana dapat disimpulkan bahwa data yang digunakan dalam model regresi ini dapat dibilang normal. Berdasarkan teori asumsi Central Limit Theorem, data yang memiliki nilai sampel lebih dari 30 dapat diasumsikan data tersebut berdistribusi normal. Setelah model dipastikan berdistribusi normal, dilakukan uji multikolinear yang menunjukkan adanya hubungan yang kuat antara dua variabel bebas atau lebih dalam model. Menurut Ghozali (2011), tidak ada gejala multikolinearitas apabila nilai VIF (Variance Inflation Factor) yang dihasilkan kurang dari 10. Dari tabel di bawah dapat dilihat bahwa VIF yang dimiliki oleh model ini tidak ada yang melebihi 10, oleh karena itu model ini dapat dikatakan bahwa tidak ada multikolinearitas pada variabel variabel bebasnya.

Tabel 3. Hasil Uji Multikolinearitas

\begin{tabular}{ll}
\hline Variabel Bebas & VIF \\
\hline Company's size & 1,0215 \\
The tangibility of assets & 1,0969 \\
Liquidity & 1,0458 \\
Asset turnover & 1,0634 \\
\hline
\end{tabular}

Sumber: Data diolah, Eviews (2019)

Pengujian asumsi berikutnya adalah uji heteroskedastisitas untuk melihat model memenuhi asumsi homoskedastisitas. Uji ini dilakukan dengan menggunakan metode Harvey-Godfrey Test di mana didapatkan hasil probabilitas di atas 5 persen, yaitu 7,56 persen. Hasil ini dapat diartikan bahwa pada data tersebut terbebas dari asumsi ini. Selain itu, model juga harus bebas dari autokorelasi yang menunjukkan keberadaan hubungan yang ada pada model seiring dengan perubahan waktu. Pada uji asumsi ini penulis menggunakan metode Durbin Watson Test dan menggunakan metode transformation first difference untuk menghilangkan terjadinya autokorelasi. Pada model ini semua data variabel yang digunakan dalam pengujian ini ditransformasikan menjadi model log dan menggunakan metode dua langkah Durbin yang berawal dari metode generalized difference equation untuk mengestimasikan $\rho$ untuk diferensiasi tahap pertama atau biasa yang disebut dengan "lag". Sehingga dihasilkan model regresi yang terbebas dari asumsi autokorelas. 
Tabel 4. Hasil Uji Asumsi Autokorelasi - Durbin Watson

\begin{tabular}{lllll}
\hline & $\mathrm{dL}$ & \multicolumn{1}{c}{1,665} & $\mathrm{dU}$ & \multicolumn{1}{c}{1,802} \\
\hline $\mathrm{dw}=2,001120$ & $\mathrm{dw}<\mathrm{dL}$ & Tidak Terpenuhi & $(4-\mathrm{dw})<\mathrm{dL}$ & Tidak Terpenuhi \\
$(4-\mathrm{dw})=1,998$ & $\mathrm{dw}>\mathrm{dU}$ & Terpenuhi & $(4-\mathrm{dw})>\mathrm{dU}$ & Terpenuhi \\
& $\mathrm{dL}<\mathrm{dw}<\mathrm{dU}$ & Tidak Terpenuhi & $\mathrm{dL}<(4-\mathrm{dw})<\mathrm{dU}$ & Tidak Terpenuhi \\
Kesimpulan & Tidak Terdapat Autokorelasi Positif & Tidak Terdapat Autokorelasi Negatif \\
\hline
\end{tabular}

Sumber: Data diolah (2019)

Dari Tabel 5 dapat dilihat bahwa probabilitas F-test yang dihasilkan kurang dari 0,05 yang menunjukkan bahwa terdapat hubungan yang signifikan secara simultan antara variabel terikat dan variabel bebasnya. Pada hasil uji ini juga didapatkan bahwa pada model ini, variabel-variabel yang digunakan dapat menjelaskan sebesar 12,3 persen. Lalu dari sisi t-test, dengan degree of freedom 132 dan alfa 5 persen didapatkan t-tabel 1,978 yang dapat menolak $\mathrm{H}_{0}$ yang menyatakan pengaruh insignifikan dari variabel bebas terhadap variabel terikat untuk semua variabel bebas yang memiliki t-hitung di luar dari range-nya, yaitu $-1,97<\mathrm{t}$-hitung $<1,97$.

Tabel 5. Hasil Regresi Model

\begin{tabular}{lrrrr}
\hline \multicolumn{1}{c}{ Variabel } & Koefisien & Std. Error & t-statistik & Probabilitas \\
\hline C & 0,446483 & 0,073782 & 6,051346 & 0,0000 \\
Company's size & $-0,232040$ & 0,219235 & $-1,058411$ & 0,2919 \\
The tangibility of asset & $-0,031656$ & 0,036927 & $-0,0857277$ & 0,3929 \\
Liquidity & $-0,378751$ & 0,082660 & $-4,582025$ & 0,0000 \\
Asset turnover & 0,011907 & 0,085524 & 0,139229 & 0,8895 \\
R-squared & 0,150218 & & F-statistik & 5,52412 \\
Adj. R-squared & 0,123025 & & Probabilitas & 0,0004 \\
\hline
\end{tabular}

Sumber: Data diolah (201

Untuk variabel bebas company's size pada hasil regresi di atas mendapatkan koefisien yang negatif terhadap leverage perusahaan, namun dari hasil t-statistik dari model regresi menunjukkan bahwa variabel ini tidak memberikan efek yang signifikan terhadap utang. Dari koefisien ini dapat dijelaskan bahwa ada hubungan yang berbanding terbalik antara company's size dan leverage perusahaan dengan anggapan semakin besar ukuran sebuah perusahaan, semakin besar pula kemampuan perusahaan tersebut dalam menghasilkan pendapatan yang cukup untuk dilakukannya internal financing. Oleh karena itu, proporsi utang perusahaan pun akan menurun. Selain berjalan searah dengan teori yang digunakan dalam penelitian, hasil dari hubungan ini juga didapatkan oleh Dang dan Li (2015) yang menyatakan bahwa company's size memiliki hubungan yang negatif terhadap leverage.

The tangibility of asset mendapatkan hasil koefisien yang negatif, hal ini menyatakan bahwa adanya hubungan yang terbalik antara variabel the tangibility of asset dan leverage dan efek yang dihasilkan dari t-statistik pada hasil regresi menyatakan bahwa variabel ini juga tidak memberikan efek yang signifikan terhadap leverage. Sehingga dapat dinyatakan bahwa The tangibility of asset tidak merepresentasikan jaminan bagi para kreditur apabila perusahaan borrower mengalami default. Hasil ini pun juga searah dengan penelitian yang dilakukan oleh Serghiescu dan Văidean (2014); Nivorozhkin (2005).

Selain the tangibility of asset, liquidity juga memiliki hasil penelitian yang sama dengan teori maupun hasil penemuan Handoo dan Sharma (2014). Liquidity pada persamaan regresi di atas memiliki koefisien yang negatif dan berdasarkan t-statistik dari hasil model regresi dapat diketahui bahwa variabel ini memberikan efek signifikan yang negatif terhadap leverage. Hal ini menunjukkan bahwa semakin likuid sebuah perusahaan tentu perusahaan tersebut akan lebih mudah untuk melakukan pembiayaan operasional daripada harus menggunakan utang sebagai modal usahanya.

Variabel terakhir pada persamaan tersebut adalah asset turnover yang memiliki hasil koefisien yang positif, namun tidak memberikan efek yang signifikan. Perusahaan dengan asset turnover yang rendah menunjukkan bahwa pendapatan yang dihasilkan perusahaan rendah relatif pada asetnya yang mengindikasikan ketidakefisienan perusahaan dalam mengelola pendapatannya sehingga perusahaan tidak dapat memakai dana internal sebagai sumber

Jurnal Manajemen dan Organisasi (JMO), Vol. 10 No. 3, Desember 2019 , Hal. 147-158 
pendanaan, dan perusahaan infrastruktur akan cenderung memilih utang sebagai pilihan kedua namun dikarenakan risiko yang meningkat, maka utang akan sulit didapatkan, sedangkan di sisi lain pemerintah sebagai sumber dana perusahaan infrastruktur telah menetapkan batas APBN bagi infrastruktur oleh karena itu, dalam situasi ini penambahan dana akan sulit didapatkan. Sehingga, menurut teori Pecking Order maka perusahaan infrastruktur, akan memilih pilihan terakhir yaitu pendanaan melalui ekuitas jika terdapat indikasi penurunan asset turnover, namun kondisi ini tidak dapat menggambarkan kondisi industri infrastruktur secara keseluruhan. Hasil penelitian ini sejalan dengan teori acuan penelitian ini dan penelitian yang telah dilakukan oleh Muritala (2018).

\section{KESIMPULAN}

Penelitian yang dilakukan mengindikasikan pemahaman komprehensif mengenai perusahaan infrastruktur dalam tujuh sektor yaitu yaitu perusahaan energi, konstruksi, nonkonstruksi bangunan, telekomunikasi, pembangunan jalan tol, transportasi, dan properti real estat yang terdaftar di BEI dari tahun 2014 sampai tahun 2018. Hipotesis penelitian mengindikasikan hubungan negatif antara company's size (SIZE), liquidity (LIQ), dan asset turnover (ATR) terhadap leverage perusahaan Infrastruktur dan hubungan positif pada the tangibility of asset (TAN), dimana hipotesis penelitian sesuai dengan teori Pecking Order Myers dan Majluf (1984). Hipotesis penelitian dilakukan sebagai arah pembanding hubungan antara tingkat utang (leverage), dengan empat eksplanatori variabel yang menjelaskan faktor internal perusahaan yaitu company's size (SIZE), the tangibility of asset (TAN), liquidity (LIQ), dan asset turnover (TURN), sehingga didapatkan hasil penemuan besar pengaruh faktor internal perusahaan terhadap tingkat utang perusahaan infrastruktur di Indonesia.

Pengolahan data menggunakan multiple regression dengan Eviews, didukung dengan uji asumsi klasik yaitu uji normalitas, multikolinearitas, autokorelasi, heteroskedastisitas, dan linieritas telah terpenuhi untuk memeriksa bahwa data yang digunakan dalam penelitian menghasilkan regresi terbaik. Selanjutnya, diperoleh hasil regresi data panel yang menyatakan hasil yang hampir serupa dengan teori Pecking Order yang mengindikasikan hubungan negatif secara signifikan antara liquidity (LIQ) terhadap leverage, namun pada komponen company's size (SIZE), the tangibility of asset (TAN), dan asset turnover (TURN) tidak memiliki pengaruh yang signifikan terhadap leverage (DAR).

Saran yang dapat dilakukan bagi manajemen perusahaan infrastruktur adalah untuk memperhatikan tingkat likuiditas perusahaan sebagai variabel yang memiliki signifikansi terhadap tingkat utang perusahaan, sehingga perusahaan infrastruktur sebaiknya menjaga tingkat likuiditas pada tingkat rata- rata industri. Hal ini dapat dijadikan pertimbangan bagi pemangku kepentingan terutama dalam pengambilan keputusan mengenai kegiatan berutang. Semakin likuiditas perusahaan menurun, perusahaan akan cenderung menggunakan utang untuk memenuhi kewajibannya. Namun jika hal ini terjadi secara berkelanjutan maka pembengkakkan utang perusahaan dapat terjadi dimana perusahaan tidak lagi perusahaan karena seiring dengan hasil penelitian, selain memberikan efek yang berbanding terbalik dari utang, likuiditas juga memberikan efek yang signifikan.

Bagi peneliti selanjutnya, disarankan untuk melakukan penelitian lebih lanjut dengan menambahkan beberapa variabel eksternal yang mempengaruhi struktur modal perusahaan infrastruktur seperti pajak, financial distress, nilai tukar valuta asing, suku bunga dan lain sebagainya. Selain itu, dalam penelitian selanjutnya juga dapat menggunakan periode yang lebih panjang dan terkini agar dapat menggambarkan keadaan terbaru pada setiap perusahaan yang terdapat di pasar modal. 


\section{DAFTAR PUSTAKA}

(n.d.). Retrieved from https://www.kemenkeu.go.id/apbn2019.

Alipour, M., Mohammadi, M. F., \& Derakhshan, H. (2015). Determinants of capital structure: An empirical study of firms in Iran. International Journal of Law and Management, 57(1), 5383. doi:10.1108/ijlma-01-2013-0004.

Bhagat, S., Bolton, B., \& Lu, J. (2015). Size, leverage, and risk-taking of financial institutions. Journal of Banking \& Finance, 59, 520-537. doi:10.1016/j.jbankfin.2015.06.018.

Buvanendra, S., Sridharan, P., \& Thiyagarajan, S. (2017). Firm characteristics, corporate governance and capital structure adjustments: A comparative study of listed firms in Sri Lanka and India. IIMB Management Review, 29(4), 245-258. doi:10.1016/j.iimb.2017.10.002.

Country/Economy Profiles. (n.d.). http://reports.weforum.org/global-competitiveness-index2017-2018/countryeconomy-profiles/\#economy=IDN.

Detthamrong, U., Chancharat, N., \& Vithessonthi, C. (2017). Corporate governance, capital structure and firm performance: Evidence from Thailand. Research in International Business and Finance, 42, 689-709. doi:10.1016/j.ribaf.2017.07.011.

Frank, M. Z., \& Goyal, V. K. (2009). Capital structure decisions: Which factors are reliably important? Financial Management, 38(1), 1-37. www.jstor.org/stable/20486683.

Handoo, A., \& Sharma, K. (2014). A study on determinants of capital structure in India. IIMB Management Review, 26(3), 170-182. doi:10.1016/j.iimb.2014.07.009.

Indef: Penugasan Infrastruktur Pemerintah Berdampak Negatif bagi BUMN. (2019, March 25). https://indonesiainside.id/indef-penugasan-infrastruktur-pemerintah-berdampak-negatifbagi-bumn/.

Kurshev \& Strebulaev. (2015). Firm Size and Capital Structure. https://www.worldscientific.com/doi/abs/10.1142/S2010139215500081.

Lamont \& Yong. (2017). Retrieved 14 April 2019 from: https://www.schroders.com/en/sysglobalassets/digital/insights/2017/pdf/ukpensions/170330-infrastructure-financing-march-2017.pdf.

Muritala, T. A. (n.d.). An Empirical Analysis of Capital Structure on Firms Performance in Nigeria. http://managementjournal.info/index.php/IJAME/article/view/214.

Myers, S. C., \& Majluf, N. S. (1984). Corporate financing and investment decisions when firms have information that investors do not have. Journal of Financial Economics, 13(2), 187221. doi:10.1016/0304-405x(84)90023-0.

Nivorozhkin, E. (2005). Financing choices of firms in EU accession countries. Emerging Markets Review, 6(2), 138-169. doi:10.1016/j.ememar.2004.10.002.

Pengertian Infrastruktur, Sistem dan juga Komponennya. (n.d.). http://www.radarplanologi.com/2015/10/apa-itu-infrastruktur.html.

Radjamin, I. J., \& Sudana, I. M. (2014). Penerapan Pecking Order Theory Dan Kaitannya Dengan Pemilihan Struktur Modal Perusahaan Pada Sektor Manufaktur Di Negara Indonesia Dan Negara Australia. Jurnal Manajemen Dan Bisnis Indonesia, 1(3), 451-468. doi:10.31843/jmbi.v1i3.35.

Ramli, N. A., Latan, H., \& Solovida, G. T. (2019). Determinants of capital structure and firm financial performance-A PLS-SEM approach: Evidence from Malaysia and Indonesia. The Quarterly Review of Economics and Finance, 71, 148-160. doi:10.1016/j.qref.2018.07.001.

Rashid, Dr. Abdul \& Mahmood, Hira. (2017). Liquidity and Capital Structure: The Case of Pakistani Non-Financial Firms. Economics Bulletin. 37. 1-12.

Serghiescu, L., \& Văidean, V. (2014). Determinant Factors of the Capital Structure of a Firm- an Empirical Analysis. Procedia Economics and Finance, 15, 1447-1457. doi:10.1016/s22125671(14)00610-8.

Jurnal Manajemen dan Organisasi (JMO),

Vol. 10 No. 3 ,

Vol. 10 No. 3,

Desember 2019 , $147-158$
Hal 
Figure 2f from: Irimia R, Gottschling M (2016) Taxonomic revision of Rochefortia Sw. (Ehretiaceae, Boraginales). Biodiversity Data Journal, 4: $\quad$ E7720. https://doi.org/10.3897/BDJ.4.e7720. (n.d.). doi:10.3897/bdj.4.e7720.figure2f.

Shoaib, K., \& Yasushi, S. (2016). Ownership and Capital Structure of Pakistani Non Financial Firms. E-Finanse, 12(1), 57-67. doi:10.1515/fiqf-2016-0136.

Thippayana, P. (2014). Determinants of Capital Structure in Thailand. Procedia - Social and Behavioral Sciences, 143, 1074-1077. doi:10.1016/j.sbspro.2014.07.558.

Yurtoğlu, N. (2018). Http://www.historystudies.net/dergi//birinci-dunya-savasinda-bir-asayissorunu-sebinkarahisar-ermeni-isyani20181092a4a8f.pdf. History Studies International Journal of History, 10(7), 241-264. doi:10.9737/hist.2018.658. 